\title{
Diversification of Cerastium sylvaticum and C. subtriflorum on the margin of the south-eastern Alps
}

\author{
Maruša Skubic $^{1,2} \cdot$ Peter Schönswetter $^{1} \cdot$ Božo Frajman $^{1}$ (D)
}

Received: 16 April 2018 / Accepted: 13 July 2018 / Published online: 20 August 2018

(c) The Author(s) 2018

\begin{abstract}
The south-eastern Alps and the southerly adjacent areas are considered an important refugium for plant species during the Pleistocene glaciations; consequently, they harbour many endemic taxa. One of them is Cerastium subtriflorum, which in this area occurs sympatrically with morphologically similar, but more widespread C. sylvaticum. Here, we used amplified fragment length polymorphisms as well as ITS and plastid DNA sequences to explore phylogenetic relationships between the two species as well as their relationships to other Cerastium taxa previously deemed closely related. Our data show that both species are genetically well-differentiated sister taxa, but their relationship to other taxa remains unclear; both species rather form an independent evolutionary lineage within European Cerastium. Cerastium sylvaticum exhibits low genetic differentiation among populations in the investigated area, suggesting a single Pleistocene refugium in that part of Europe. The much more pronounced genetic differentiation within C. subtriflorum is likely a result of multiple Pleistocene refugia or more recent vicariance among the three disjunct partial distribution areas. Phylogenetic sequence data suggest hybridisation between the two taxa, resulting in a discordant phylogenetic position between ITS and plastid trees of one population of $C$. subtriflorum. Flow cytometric and multivariate morphometric analyses show that $C$. subtriflorum and $C$. sylvaticum differ in their genome size as well as in multiple morphological traits. We provide a taxonomic treatment for both species including an identification key and species descriptions.
\end{abstract}

Keywords AFLP · Endemism · Genome size · Phylogenetic analyses · South-eastern Alps · Taxonomy

\section{Introduction}

The south-eastern Alps and the southerly adjacent areas have been considered an important refugium for Alpine biota during Pleistocene glaciations (Tribsch and Schönswetter 2003; Schmitt 2009) as the southern margin of the Eastern Alps was not entirely covered with an ice sheet during the Last Glacial Maximum, thus enabling the survival of plant

Handling Editor: Michal Ronikier.

Electronic supplementary material The online version of this article (https://doi.org/10.1007/s00606-018-1535-y) contains supplementary material, which is available to authorized users.

Božo Frajman

bozo.frajman@uibk.ac.at

1 Department of Botany, University of Innsbruck, Sternwartestrasse 15, 6020 Innsbruck, Austria

2 Department of Biology, Biotechnical Faculty, University of Ljubljana, Večna pot 111, 1000 Ljubljana, Slovenia species (Tribsch and Schönswetter 2003; Schönswetter et al. 2005; Alvarez et al. 2009). As in other glacial refugia in the Alps (Pawłowski 1970; Tribsch and Schönswetter 2003), also the south-eastern Alps harbour many endemic species; more than 60 endemic plant taxa have been listed for this area (Mayer 1960a, b; Wraber 1990), for instance Aconitum angustifolium Bernh. ex Rchb. (Ranunculaceae), Athamanta turbith (L.) Brot. (Apiaceae), Campanula zoysii Wulfen (Campanulaceae), Cerastium julicum Schellm. (Caryophyllaceae), Gentiana froelichii Jan ex Rchb. (Gentianaceae) and Moehringia villosa (Wulfen) Fenzl (Caryophyllaceae). Not only alpine plants survived the glaciations in this part of Europe; there is also evidence for existence of broadleaved forests in the areas southerly adjacent to the southeastern Alps, which were suggested as likely refugia for oaks (Quercus sp.; Petit et al. 2002) and beech (Fagus sylvatica L.; Magri et al. 2006) as well as for several beech forest understory herbs (Willner et al. 2009), including Knautia drymeia Heuff. (Caprifoliaceae; Rešetnik et al. 2016), Cyclamen purpurescens Mill. (Primulaceae; Slovák et al. 
2012) and Veronica chamaedrys L. (Plantaginaceae; Bardy et al. 2010).

One of endemic species of the south-eastern Alps is Cerastium subtriflorum (Rchb.) Pacher (Caryophyllaceae). It has a disjunct distribution similar to some other species, for instance Saxifraga tenella Wulfen (Mayer 1960a). They both can be found in the Julian Alps of Italy and Slovenia, along the southern margins of Kamniške Alpe and in the Sava river valley in central Slovenia (Jalas and Suominen 1983; Poldini 2002; Jogan et al. 2001), growing from the lowlands to the alpine vegetation belt. Cerastium subtriflorum was described by Reichenbach (1841) as a variety, C. lanuginosum Willd $\beta$. subtriflorum, based on specimens collected on Mt. Mangart (Julian Alps, Slovenia) by H. Freyer and distributed under the name "C. latifolium subtriflorum Rchb." in Reichenbach's Flora Germanica Exsiccata (nr. 1493). It was raised to the species level by Pacher (1886). Beck (1908) separated lowland populations of $C$. subtriflorum from the Soča valley in Slovenia as C. sonticum Beck, which was later treated conspecific with C. subtriflorum (Mayer 1960a; Jalas 1964). Beck (1908) considered both species closely related to $C$. sylvaticum Waldst. \& Kit., which is a forest species, distributed in the lowlands of Central and Eastern Europe, with isolated disjunct occurrences in Albania, Italy, Romania, south-western Ukraine, Moldova and northern Poland. In Slovenia, its range overlaps largely with that of C. subtriflorum (Jalas and Suominen 1983; Jogan et al. 2001) and both species are difficult to distinguish when not flowering.

Despite the fact that many Cerastium species are high polyploids (e.g. Brysting et al. 2011; Niketić et al. 2013; Rice et al. 2015 and references therein), C. sylvaticum and C. subtriflorum are both tetraploids (Söllner 1954; Rice et al. 2015), which is the lowest ploidy level known in Cerastium; we consider the diploid count for C. lithospermifolium Fisch. by Krogulevich (1971) erroneous, as it was never confirmed again nor discovered in any other species (Niketić et al. 2013; Rice et al. 2015). Two main morphological characters distinguishing the two species are petal size and the shape of lowermost stem leaves and stolon leaves (Pignatti 1982; Jalas 1993; Vreš 1996, 2007), but the phylogenetic relationships between them and in relation to other Cerastium species remain unknown. Graebner and Correns (1918) included both $C$. subtriflorum and C. sylvaticum with several other, predominantly Alpine species (C. carinthiacum Vest, C. dinaricum Beck \& Szyszył., C. fontanum Baumg., C. latifolium L., C. pedunculatum Gaud. ex Ser., C. rectum Friv., C. uniflorum Clairv.) in C. sect. Latifolia Borza, which was followed by Niketić (2007), who included C. subtriflorum together with C. carinthiacum, C. dinaricum, C. latifolium, C. runemarkii Möschl \& Rech.f., C. theophrasti Merxm. $\&$ Strid and C. uniflorum into C. ser. Latifolia Borza. On the other hand, Božo Friedrich (1969) treated C. subtriflorum and $C$. sylvaticum together with $C$. fontanum in $C$. sect.
Caespitosa Pax \& Hoffm. (=C. sect. Vulgata Hayek), thus separated from the $C$. latifolium alliance.

In order to disentangle relationships between the southeastern Alpine endemic $C$. subtriflorum and the more widespread C. sylvaticum and to infer their relationships to other taxa, we here used a combination of phylogenetic analyses, relative genome size (RGS) measurements and multivariate morphometrics. More specifically, we (1) used ITS and plastid DNA sequences as well as amplified fragment length polymorphisms (AFLPs) to explore the relationships between both species and to infer their position within Cerastium, (2) analysed whether the two species differ in their relative genome size despite having the same chromosome number and (3) searched for additional morphological characters to distinguish between both species in vegetative stage using a multivariate morphometric approach. Based on this integrative approach, we provide a taxonomic treatment for both species, including detailed descriptions and an identification key.

\section{Materials and methods}

\section{Plant material}

Leaf material of one to five individuals per population from nine populations of $C$. subtriflorum and five of C. sylvaticum was collected and stored in silica gel for molecular and RGS analyses; the exception is population 5, where freshly collected herbarium material was used for RGS measurements and DNA sequencing. Altogether, ITS and the plastid DNA region $n d h \mathrm{~J}-\operatorname{tr} n \mathrm{~T}$ was sequenced for 14 populations, for which also RGS data were obtained, and 11 populations were included in AFLP analyses. Some additional populations of $C$. subtriflorum and C. sylvaticum were collected for morphometric analyses, for which also additional specimens from the herbaria LJU, WU, TSB and ZA were studied, resulting in a data set of 38 individuals of $C$. subtriflorum and 46 of $C$. sylvaticum. Voucher data of all studied populations, including the four out-group taxa sequenced, are presented in Online Resource 1. Distribution of all analysed in-group populations is shown in Fig. 1, where also the geographic position of all inspected herbarium specimens of $C$. subtriflorum from the herbaria IB, LJU, TSB, WU, W and ZA is shown.

\section{Sequencing and phylogenetic analyses of ITS and $n d h J-t r n T$}

Extraction of total genomic DNA was performed following the modified CTAB-protocol of Tel-Zur et al. (1999). Four regions $\left(p e t \mathrm{~N}(y c f 6)-p s b \mathrm{M}, t r n \mathrm{~L}^{(\mathrm{UAG})}-n d h \mathrm{~F}, n d h \mathrm{~J}-t r n \mathrm{~T}\right.$, $\operatorname{trn} \mathrm{Q}-\operatorname{trn} \mathrm{K})$ of the plastid genome have been tested for 


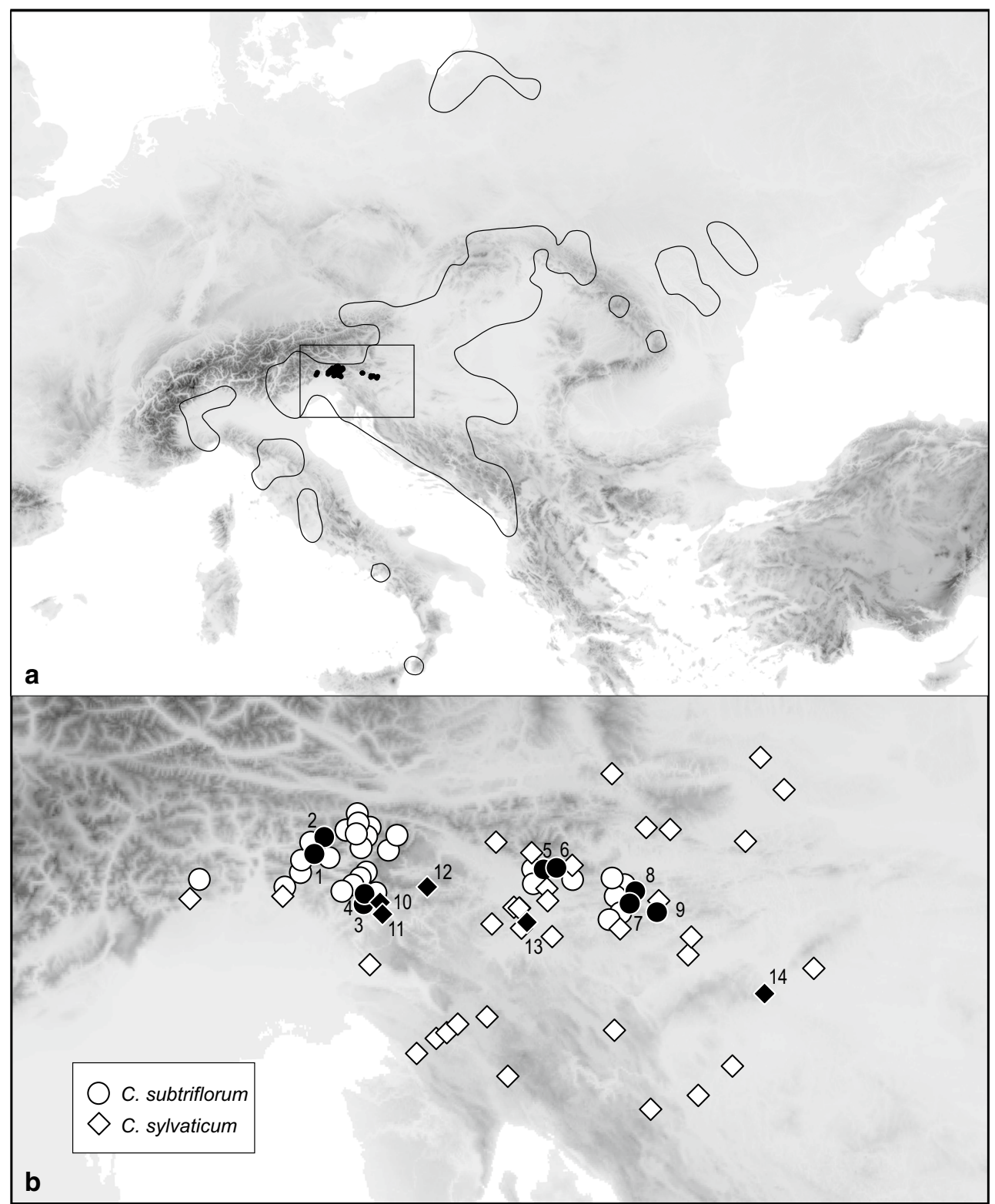

Fig. 1 Distribution area and sampled populations of Cerastium subtriflorum and C. sylvaticum. a Distribution of C. subtriflorum based on revised herbarium material and shown by black dots, and that of C. sylvaticum shown by polygons modified from Jalas and Suominen (1983). b Populations sampled for genetic (black symbols) and mor-

variation among different Cerastium species prior the study. The $n d h \mathrm{~J}-t r n \mathrm{~T}$ region yielded the highest variability and was thus sequenced in this study. PCR and sequencing of ITS and the plastid $n d h \mathrm{~J}$-trnT region were performed for one to two individuals per population (Table 1) as described by Kutnjak et al. (2014), with the exception that sequencing was carried out at Eurofins Genomics (Ebersberg, Germany). Contigs were assembled, edited and sequences were aligned using Geneious Pro 5.5.9 (Kearse et al. 2012). Base polymorphisms were coded using NC-IUPAC ambiguity phological (white symbols) analyses. All populations except population 14 used in genetic analyses were analysed also morphometrically. Population 85 from Bosnia and Herzegovina and populations 81, 82, 83 and 84 from Austria studied in morphometric analyses are not shown. Population numbers correspond to Online Resource 1

codes. ITS and plastid alignments are in Online Resources 2 and 3, respectively. GenBank numbers of C. subtriflorum and $C$. sylvaticum sequences are presented in Table 1 and those of the out-group taxa in Online Resource 1.

Gaps (indels) in the plastid data set were coded as binary characters using SeqState version 1.25 (Müller 2005). Maximum parsimony (MP) and MP bootstrap (MPB) analyses of ITS and plastid data sets were performed using PAUP 4.0b10 (Swofford 2002). The most parsimonious trees were searched for heuristically with 
Table 1 List of populations of Cerastium subtriflorum and $C$. sylvaticum included in genetic analyses and relative genome size measurements

\begin{tabular}{|c|c|c|c|c|c|c|}
\hline ID & Taxon & ITS & $N d h \mathrm{~J}-t r n \mathrm{~T}$ & N AFLP & N RGS & $\mathrm{RGS} \pm \mathrm{SD}$ \\
\hline 1 & C. subtriflorum & MH478076 & $\begin{array}{l}\text { MH487895, } \\
\text { MH487897 }\end{array}$ & 3 & 5 & $0.277 \pm 0.001$ \\
\hline 2 & C. subtriflorum & MH537033 & MH488066 & - & 1 & $0.271 \pm 0.000$ \\
\hline 3 & C. subtriflorum & MH537035 & MH487896 & 4 & 5 & $0.275 \pm 0.002$ \\
\hline 4 & C. subtriflorum & MH478077 & MH487898 & 4 & 2 & $0.258 \pm 0.000$ \\
\hline 5 & C. subtriflorum & MH537032 & MH488067 & - & 1 & $0.265 \pm 0.000$ \\
\hline 6 & C. subtriflorum & MH478080, MH478081 & $\begin{array}{l}\text { MH488027, } \\
\text { MH488028 }\end{array}$ & 3 & 4 & $0.253 \pm 0.019$ \\
\hline 7 & C. subtriflorum & MH537034 & MH488065 & 5 & 5 & $0.243 \pm 0.022$ \\
\hline 8 & C. subtriflorum & MH478078, MH478079 & $\begin{array}{l}\text { MH487900, } \\
\text { MH487901 }\end{array}$ & 5 & 5 & $0.285 \pm 0.005$ \\
\hline 9 & C. subtriflorum & MH478075 & MH487899 & 5 & 5 & $0.272 \pm 0.007$ \\
\hline 10 & C. sylvaticum & MH478082 & MH488030 & - & 3 & $0.297 \pm 0.008$ \\
\hline 11 & C. sylvaticum & MH478086 & $\begin{array}{l}\text { MH488026, } \\
\text { MH488029 }\end{array}$ & 3 & 5 & $0.306 \pm 0.002$ \\
\hline 12 & C. sylvaticum & MH478084 & MH488031 & 5 & 4 & $0.309 \pm 0.001$ \\
\hline 13 & C. sylvaticum & MH478085 & MH488033 & 5 & 5 & $0.303 \pm 0.007$ \\
\hline 14 & C. sylvaticum & MH478083 & MH488032 & 5 & 2 & $0.304 \pm 0.006$ \\
\hline
\end{tabular}

ID Population numbers as in Fig. 1 and Online Resource 1; ITS ITS GenBank number; $n d h \mathrm{~J}-t r n \mathrm{~T}$, $n d h \mathrm{~J}$ $\operatorname{trn}$ T GenBank number; $N A F L P$ number of individuals investigated with amplified fragment length polymorphism; $N R G S$ number of individuals included in the relative genome size measurements; $R G S$ $\pm S D$ relative genome size with standard deviation
1000 replicates of random sequence addition, TBR swapping and MulTrees on. The swapping was performed on a maximum of 1000 trees (nchuck $=1000$ ). All characters were equally weighted and unordered. The data set was bootstrapped using full heuristics, 1000 replicates, TBR branch swapping, MulTrees option off, and random addition sequence with five replicates. The out-group taxa C. carinthiacum, C. dinaricum, C. eriophorum Kit. ex Rochel, C. fontanum Baumg. and C. latifolium were used for rooting.

Bayesian analyses were performed with MrBayes 3.2.1 (Ronquist et al. 2012) applying the GTR (ITS) and F81 (plastid dataset) substitution models proposed by the Akaike information criterion implemented in MrAIC.pl 1.4 (Nylander 2004). In the case of the plastid analyses, the data were partitioned into a nucleotide data set and an indel data set; the latter was treated as morphological data according to the model of Lewis (2001). Values for all parameters, such as the shape of the gamma distribution, were estimated during the MrBayes analyses. The settings for the Metropolis-coupled Markov chain Monte Carlo process included four runs with four chains each (three heated ones using the default heating scheme), run simultaneously for $10,000,000$ generations each, sampling trees every 1000th generation using default priors. The posterior probabilities (PP) of the phylogeny and its branches were determined from the combined set of trees, discarding the first 1001 trees of each run as burn-in.
In addition, a NeighbourNet was produced with ITS sequences of $C$. subtriflorum and $C$. sylvaticum using SplitsTree4 12.3 (Huson and Bryant 2006) and the plastid ingroup sequences were analysed using statistical parsimony as implemented in TCS (Clement et al. 2000) with the connection limit set to 95; gaps were treated as fifth character state. For this analysis, indels longer than $1 \mathrm{bp}$ were reduced to single base-pair columns allowing those structural mutations to be counted as single base-pair mutations only.

\section{AFLP analyses}

The number of individuals per population used in AFLP analyses is presented in Table 1. The AFLP procedure followed Vos et al. (1995) with the modifications described in Schönswetter et al. (2009). In addition, $0.25 \mathrm{U}$ of polymerase was used in the preselective and selective amplifications ( $0.4 \mathrm{U}$ for the NED-labelled primer combination). The primer combinations for the selective PCR (fluorescent dye in brackets) were EcoRI (6-FAM)ACA/MseI-CAT, $E c o$ RI (VIC)AAG/MseI-CTT, EcoRI (NED)AGC/MseICTG (6-FAM-labelled primers: Sigma-Aldrich; NED- and VIC-labelled primers: Applied Biosystems). Purification and visualisation of PCR products were done as described in Rebernig et al. (2010). Analysis of electropherograms and scoring of the AFLP fragments were performed as described in Caković et al. (2017), with the exception that the minimum intensity used in RawGeno was set to 75 relative 
fluorescence units. This analysis was performed on a data set including several out-group taxa, altogether including seven replicates to test the reproducibility (Bonin et al. 2004). The error rate was calculated as the mean value of error rates for each primer combination obtained with RawGeno 2.0-1 (Arrigo et al. 2009) in R 2.15.2 (R Development Core Team 2012). Fragments present/absent in only one individual were deleted.

A preliminary neighbour-joining (NJ) analysis based on a Nei-Li genetic distance matrix (Nei and Li 1979) was constructed and bootstrapped (2000 pseudo-replicates) using TREECON v.1.3b (van de Peer and Wachter 1997). Cerastium subtriflorum and $C$. sylvaticum formed a monophyletic clade (bootstrap support, BS, 100\%) with unresolved relationships to other taxa; therefore, the data set including only these two species was further analysed, i.e. a NJ tree was generated as described above and a NeighbourNet of C. subtriflorum was produced with SplitsTree4 12.3 (Huson and Bryant 2006).

\section{Relative genome size (RGS) estimation and statistical analyses}

The RGS of silica gel-dried leaves of C. subtriflorum and $C$. sylvaticum was estimated using flow cytometry as described by Kutnjak et al. (2014) for one to five individuals per population (Table 1). Despite the fact that the coefficient of variation (CV) of the G0/G1 peak of the sample exceeded the $5 \%$ threshold in four populations, we included these data in further analyses as the peaks were clearly visible and the RGS values highly similar to the RGS values obtained in other populations. Statistical analyses of the RGS data were carried out with R-3.3.2 (R Development Core Team 2016) and the visualisation package 'ggplot2'. Mean RGS values for populations of both species were tested for normality using a Shapiro-Wilk test. Subsequently, RGS values were compared using Welch's two-sample $t$ test.

\section{Morphometric analyses}

Material for morphometric analyses of most characters included 56 individuals, 25 of $C$. subtriflorum and 31 of $C$. sylvaticum (Online Resource 1). In some of these plants, fruit and seed characters were missing and were measured on 13 and 15 additional specimens of $C$. subtriflorum and C. sylvaticum, respectively, resulting in data set of 84 individuals (Online Resource 1). Altogether, 67 morphological characters were studied (Table 2), including 16 ratio characters calculated on the basis of measured characters. Certain characters were missing in some individuals and were thus replaced with the mean values calculated for the other studied populations of the same species.
Leaf characters with the exception of trichome characters were measured with the program imageJ (Schneider et al. 2012), stem and inflorescence characters were scored manually and the remaining characters were measured under the stereo microscope Olympus SZX9 equipped with an Olympus UC30 camera and SZX9 telephoto lens using the Olympus image analysis software analysis Pro. Petals and sepals were softened in hot water and spread on plastic foil. Analyses of morphometric data were performed with IBM SPSS Statistics (version 24). Capsule and seed characters were analysed separately, because they were partly measured on other individuals as the remaining characters (see above and Online Resource 1), resulting in a data set of 20 C. subtriflorum and 22 C. sylvaticum individuals. Due to the small number of $C$. subtriflorum individuals with developed stolon leaves (12 C. subtriflorum and 24 C. sylvaticum; Online Resource 1), we also analysed these characters separately. Correlation among metric characters was tested employing Pearson or Spearman correlation coefficients, which exceed 0.90 in five pairs of characters: width of petal lobe/petal width, petal length/distance from the basis to the widest part of the petal, petal length/petal length from the basis to the incision, length of a mid-stem leaf/distance from the basis to the widest part of a mid-stem leaf, length of a stolon leaf/distance from the basis to the widest part of a lowermost leaf; second listed character was excluded from further analyses.

We produced boxplot diagrams for all characters in order to explore the variation between the two taxa. After standardisation to zero mean and unit variance, a principal component analysis (PCA) was performed. Discriminant analysis (DA) was applied to inspect the separation between $C$. subtriflorum and $C$. sylvaticum and the relative importance of characters discriminating between them. All these three analyses were performed for each of the three data sets separately (capsule and seeds, stolon leaves, other characters). Values presented in the identification key and the species descriptions correspond to the 10 and $90 \%$ percentiles, supplemented by extreme values in parentheses.

\section{Results}

\section{ITS and $n d h J-t r n T$ sequences}

Topologies of the trees inferred by parsimony and Bayesian analyses were congruent in both sequence data sets. In the ITS tree (Fig. 2a), C. dinaricum and $C$. eriophorum were most divergent, followed by $C$. fontanum. Cerastium carinthiacum and $C$. latifolium formed a highly supported clade (MPB 85\%, PP 1), which was sister to the clade including C. subtriflorum and C. sylvaticum (MPB 100\%, PP 1). Within the latter clade, relationships were poorly resolved; only $C$. sylvaticum was weakly supported in the parsimony 
Table 2 Morphometric characters studied in Cerastium subtriflorum and C. sylvaticum

\begin{tabular}{|c|c|}
\hline No. & Character \\
\hline \multicolumn{2}{|c|}{ Petal } \\
\hline 1 & Petal length, mm \\
\hline 2 & Petal width, mm \\
\hline 3 & Width of petal lobe, $\mathrm{mm}$ \\
\hline 4 & Ratio petal length/petal width \\
\hline 5 & Distance from the basis to the widest part of the petal, $\mathrm{mm}$ \\
\hline 6 & Ratio distance from the basis to the widest part of the petal/petal length \\
\hline 7 & Petal length from the basis to the incision, $\mathrm{mm}$ \\
\hline 8 & Ratio petal length from basis to the incision/petal length \\
\hline \multicolumn{2}{|c|}{ Sepal } \\
\hline 9 & Sepal length, mm \\
\hline 10 & Sepal width, mm \\
\hline 11 & Ratio sepal width/sepal length \\
\hline 12 & Distance from the basis to the widest part of the sepal, $\mathrm{mm}$ \\
\hline 13 & Ratio distance from the basis to the widest part of the sepal/sepal length \\
\hline 14 & Width of hyaline margin of sepal, mm \\
\hline 15 & Ratio petal length/sepal length \\
\hline \multicolumn{2}{|l|}{ Leaf } \\
\hline \multicolumn{2}{|c|}{ Mid-stem leaf } \\
\hline 16 & Length of a mid-stem leaf, mm \\
\hline 17 & Width of a mid-stem leaf, mm \\
\hline 18 & Ratio length of a mid-stem leaf/width of a mid-stem leaf \\
\hline 19 & Distance from the basis to the widest part of a mid-stem leaves, $\mathrm{mm}$ \\
\hline 20 & Ratio distance from the basis to the widest part of a mid-stem leaves/length of a mid-stem leaf \\
\hline 21 & Angle of the apex of a mid-stem leaf, ${ }^{\circ}$ \\
\hline 22 & Angle of the base of a mid-stem leaf, ${ }^{\circ}$ \\
\hline \multicolumn{2}{|c|}{ Lowermost leaf } \\
\hline 23 & Length of a lowermost leaf, mm \\
\hline 24 & Width of a lowermost leaf, mm \\
\hline 25 & Ratio length of a lowermost leaf/width of a lowermost leaf \\
\hline 26 & Distance from the basis to the widest part of a lowermost leaf, mm \\
\hline 27 & Ratio distance from the basis to the widest part of a lowermost leaf/length of a lowermost leaf \\
\hline 28 & Angle of the apex of a lowermost leaf, ${ }^{\circ}$ \\
\hline 29 & Angle of the base of a lowermost leaf, ${ }^{\circ}$ \\
\hline 30 & Petiole length of a lowermost leaf, mm \\
\hline \multicolumn{2}{|c|}{ Stolon leaf } \\
\hline 31 & Length of a stolon leaf, mm \\
\hline 32 & Width of a stolon leaf, mm \\
\hline 33 & Ratio length of a stolon leaf/width of a stolon leaf \\
\hline 34 & Distance from the basis to the widest part of a lowermost leaf, mm \\
\hline 35 & Ratio distance from the basis to the widest part of a lowermost leaf/length of a stolon leaf \\
\hline 36 & Angle of the apex of a stolon leaf, ${ }^{\circ}$ \\
\hline 37 & Angle of the base of a stolon leaf, ${ }^{\circ}$ \\
\hline 38 & Petiole length of a stolon leaf, mm \\
\hline \multicolumn{2}{|c|}{ Capsule } \\
\hline 39 & Capsule length, mm \\
\hline 40 & Capsule width, mm \\
\hline 41 & Ratio capsule length/capsule width \\
\hline 42 & Distance from the basis to the widest part of the capsule, $\mathrm{mm}$ \\
\hline 43 & Ratio distance from the basis to the widest part of the capsule/capsule length \\
\hline
\end{tabular}


Table 2 (continued)

\begin{tabular}{|c|c|}
\hline No. & Character \\
\hline 44 & Angle of capsule (curved or straight), ${ }^{\circ}$ \\
\hline 45 & Capsule teeth length, mm \\
\hline 46 & Capsule teeth width, mm \\
\hline 47 & Ratio capsule teeth length/capsule teeth width \\
\hline \multicolumn{2}{|c|}{ Seed } \\
\hline 48 & Seed length, mm \\
\hline 49 & Seed width, mm \\
\hline 50 & Ratio seed length/seed width \\
\hline 51 & Length of tubercles on the seed, $\mathrm{mm}$ \\
\hline 52 & Width of tubercles on the seeds, $\mathrm{mm}$ \\
\hline \multicolumn{2}{|c|}{ Stem } \\
\hline 53 & Stem height, mm \\
\hline 54 & Stem width on the basis, mm \\
\hline 55 & Length of internode adjacent to the mid-stem leaves, $\mathrm{mm}$ \\
\hline 56 & Number of internodes below dichasium \\
\hline \multicolumn{2}{|c|}{ Inflorescence } \\
\hline 57 & Length of peduncle of terminal flower, mm \\
\hline 58 & Length of inflorescence from the basal flower to the top, $\mathrm{mm}$ \\
\hline \multicolumn{2}{|c|}{ Trichomes } \\
\hline 59 & Number of trichomes along $1 \mathrm{~mm}$ on the pedunculus of the terminal flower \\
\hline 60 & Length of trichomes on the sepal (average of six measured trichomes), mm \\
\hline 61 & $\begin{array}{l}\text { Number of eglandular hairs per } 1 \mathrm{~mm}^{2} \text { on the upper epidermis of a mid-stem leaf, calculated as the average of } \\
\text { two squares with } 1 \mathrm{~mm}^{2} \text { each }\end{array}$ \\
\hline 62 & Number of glandular hairs on the margin of a mid-stem leaf along $1 \mathrm{~mm}$ just below the tip of the leaf \\
\hline 63 & Number of eglandular hairs on the margin of a mid-stem leaf along $1 \mathrm{~mm}$ just below the tip of the leaf \\
\hline 64 & Length of the longest trichome on the margin of a mid-stem leaf along $1 \mathrm{~mm}$ just below the tip of the leaf, $\mathrm{mm}$ \\
\hline 65 & Number of glandular hairs on the stem along $1 \mathrm{~mm}$ just below a mid-stem leaf \\
\hline 66 & Number of eglandular hairs on the stem along $1 \mathrm{~mm}$ just below a mid-stem leaf \\
\hline 67 & Length of the longest trichome on the stem along $1 \mathrm{~mm}$ just below a mid-stem leaf, $\mathrm{mm}$ \\
\hline
\end{tabular}

tree (MPB 71\%, PP 0.76). In the NeighbourNet (Fig. 2b), $C$. sylvaticum and $C$. subtriflorum were divergent; populations 5,7 and 8 of the latter from central Slovenia were intermediate between the two species albeit connected with a shorter split with other populations of the same species.

Relationships between $C$. subtriflorum/C. sylvaticum and the out-group taxa were poorly resolved in the plastid tree (Fig. 2c). Cerastium dinaricum was sister to a clade (MPB $99 \%$, PP 1) including the in-group taxa and $C$. fontanum, but with poor support (PP 0.97). Relationships between $C$. fontanum, $C$. subtriflorum and $C$. sylvaticum were unresolved, as the clade including most of the $C$. subtriflorum accessions and $C$. fontanum had low support (MPB 54\%, PP 0.88). Population 6 of $C$. subtriflorum was positioned within C. sylvaticum with strong support (MPB 99\%, PP 1). All other populations of $C$. subtriflorum formed another well-supported clade (MPB 90\%, PP 1). The differences between $C$. subtriflorum and $C$. sylvaticum were solely based on indel characters, whereas the nucleotide sequences were identical in all accessions. In the statistical parsimony network (Fig. 2d), all C. sylvaticum sequences (including population 6 of $C$. subtriflorum) were identical, whereas the other accessions of $C$. subtriflorum were variable, resulting in eight different haplotypes.

\section{AFLP data}

For the 172 individuals of the data set including other Cerastium species, 639 fragments were scored. The error rate before the exclusion of unreproducible fragments was $3.4 \%$. Before the neighbour-joining tree of $C$. subtriflorum and $C$. sylvaticum was inferred, 311 monomorphic bands or those present or absent in only one individual were excluded. Before the NeighbourNet of $C$. subtriflorum was constructed, 71 additional monomorphic bands have been excluded.

The neighbour-joining tree (Fig. 3a) showed a clear separation between $C$. subtriflorum and $C$. sylvaticum with 
Fig. 2 Phylogenetic relationships inferred by ITS $(\mathbf{a}, \mathbf{b})$ and plastid $n d h \mathrm{~J}-t r n \mathrm{~T}(\mathbf{c}, \mathbf{d})$ sequences. Population identifiers correspond to Online Resource 1 and Fig. 1. a, c Bayesian consensus phylograms. Numbers above branches are maximum parsimony bootstrap values $>50 \%$, those below branches posterior probabilities $>0.50$. b NeighbourNet diagram of ITS sequences. $\mathbf{d}$ Statistical parsimony network of plastid DNA haplotypes. The size of the circles is relative to the square root of a haplotype's frequency. Haplotypes not sampled are shown as small black dots
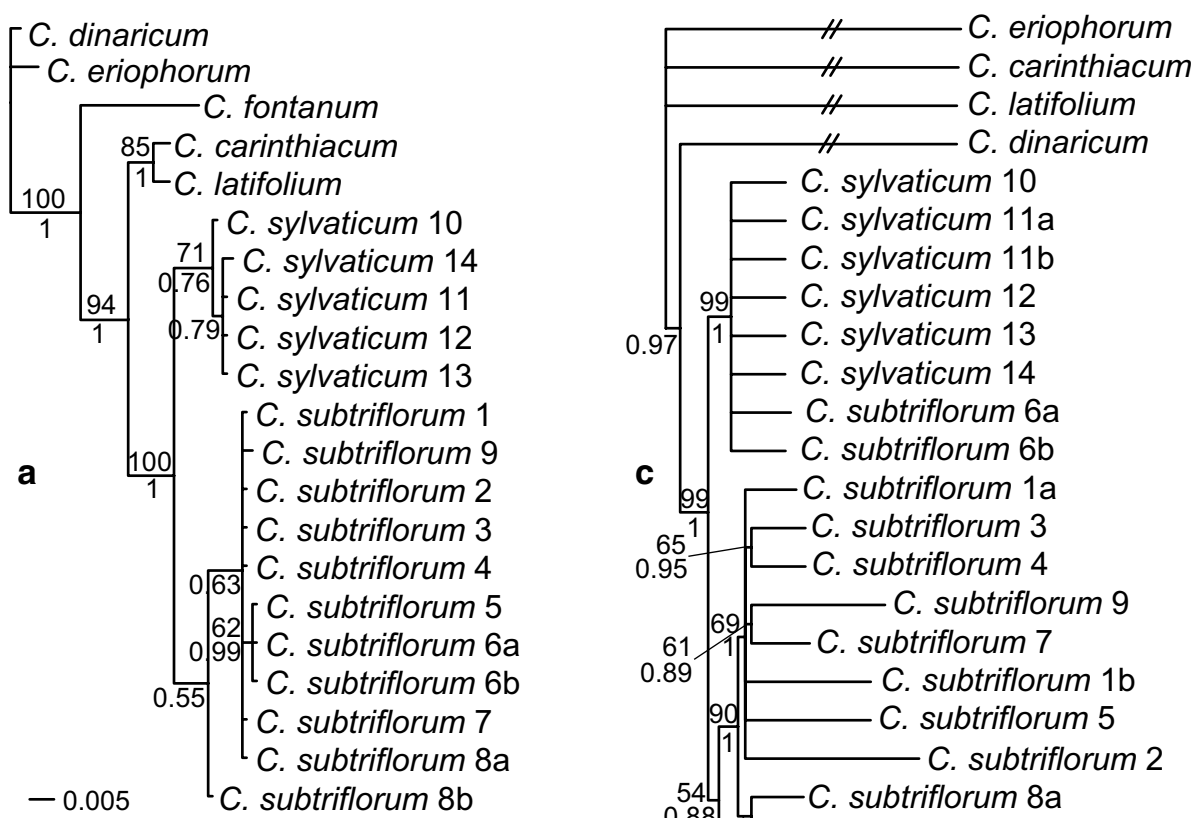

C. eriophorum

C. latifolium

C. sylvaticum 10

C. sylvaticum $11 \mathrm{a}$

C. sylvaticum $11 \mathrm{~b}$

C. sylvaticum 12

1 - C. sylvaticum 13

C. sylvaticum 14

C. subtriflorum $6 a$

C. subtriflorum 6b

C

c C. subtriflorum $1 \mathrm{a}$

$65^{1} \quad$ C. subtriflorum 3

$0.95 \quad C$. subtriflorum 4

617 C. subtriflorum 7

0.89 C. subtriflorum $1 \mathrm{~b}$

C. subtriflorum 5

C. subtriflorum 2

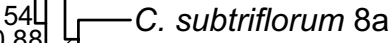

0.88 Y C. subtriflorun

1 C. fontanum $-0.00006$

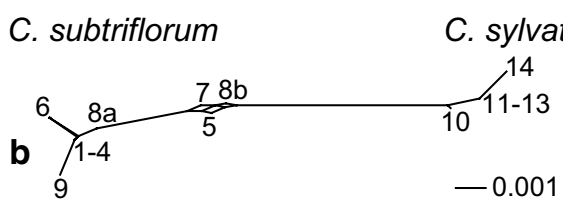

ITS

d

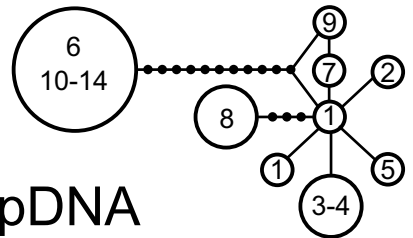

high bootstrap support (BS 100). Within C. subtriflorum, population 6 from central Slovenia was sister to all other populations, with unresolved relationships among them; only populations 1 and 3 grouped together (BS 86\%). The NeighbourNet of C. subtriflorum (Fig. 3b) was star-like. Population 6 shared some splits with populations 1,3 and 4 from western Slovenia, whereas populations 7, 8 and 9, all from the Sava river valley, were positioned on the other side of the same split. In C. sylvaticum, two main groups were resolved in the neighbour-joining tree, one including population 12 (BS 98\%) from Western Slovenia and the other included all remaining populations (BS 72\%).

\section{Relative genome size estimation}

The RGS values of $C$. subtriflorum ( $n=9$; Shapiro-Wilk, $p=0.8266)$ and $C$. sylvaticum ( $n=5$; Shapiro-Wilk, $p=0.8434$ ) showed a normal distribution. Mean RGS of $C$. subtriflorum populations ranged between 0.243 and 0.285 , and that of C. sylvaticum between 0.297 and 0.309 (Table 1, Fig. 4). Differences in mean RGS values of both species were significant (Welch's two-sample t test, $p=1.11 \times 10^{-5}$, $p<0.001)$.

\section{Morphological differentiation between Cerastium subtriflorum and C. sylvaticum}

For all characters excluding capsule and seed characters, measured values and ratios are presented in Online Resource 4; for capsule and seed character they are given in Online Resource 5. The first three axes of the PCA of all characters excluding capsule, seed and stolon leaf characters explained 26.14, 13.04 and $7.76 \%$ of the total variation (Fig. 5a). A clear separation between C. subtriflorum (Fig. 3c) and C. sylvaticum (Fig. 3d) was obvious along the first axis, whereas there was no visible pattern along the second and third axes. The characters contributing most to the separation along the first axis, i.e. those having highest component scores (between 0.62 and 0.90), were petal and sepal characters (petal length, width of petal lobe, ratio petal length/sepal length), leaf characters (length of a mid-stem leaf, width of a mid-stem leaf, angle of the base of a mid-stem leaf, width of a lowermost leaf, petiole length of a lowermost leaf), stem height and trichome characters (number of eglandular hairs on the margin of a mid-stem leaf along $1 \mathrm{~mm}$ just below the tip of the leaf, length of the longest trichome on the margin of a mid-stem leaf along $1 \mathrm{~mm}$ just below the tip of the leaf and number of glandular hairs on the 


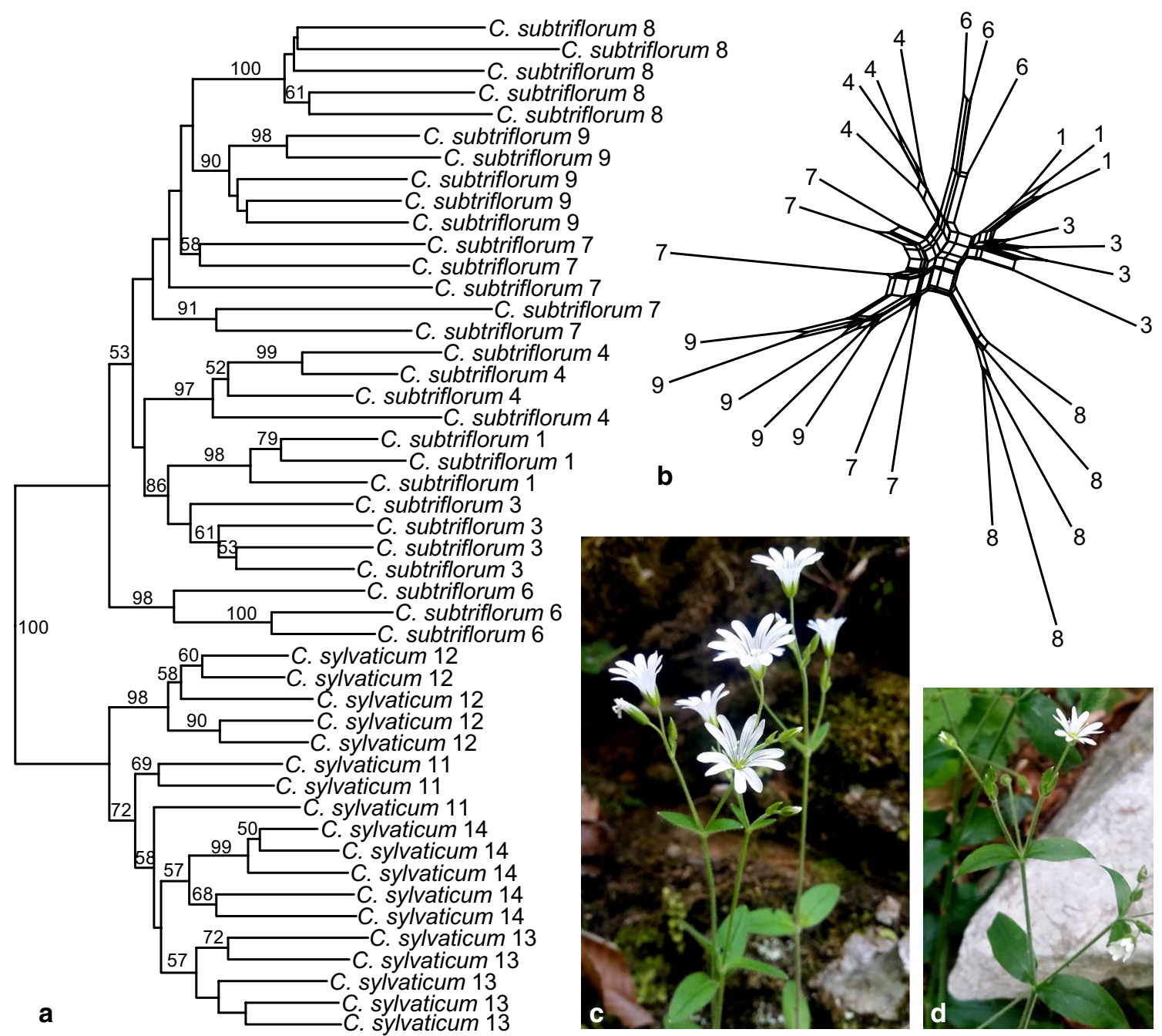

Fig. 3 Relationships between Cerastium subtriflorum (c) and C. sylvaticum (d) inferred with AFLP data. a Neighbour-joining tree. b NeighbourNet diagram of $C$. subtriflorum. Population identifiers correspond to Online Resource 1 and Fig. 1. Photographs by M. J. Kocjan

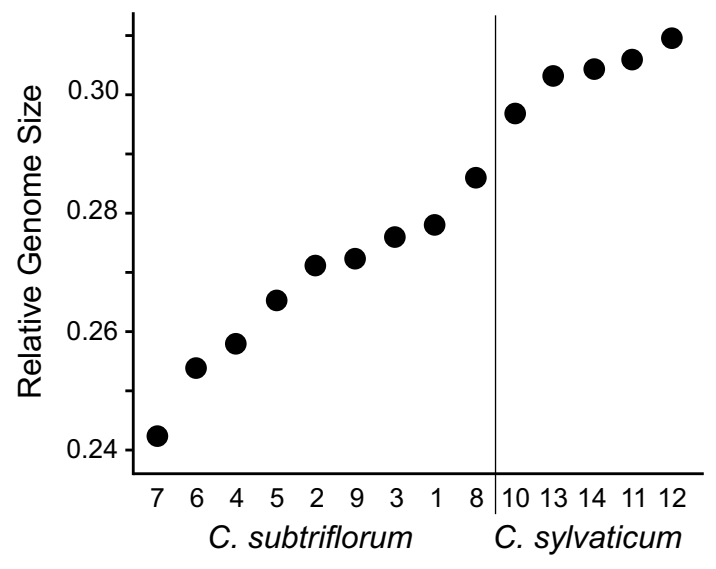

Fig. 4 Relative genome size variation in Cerastium subtriflorum and C. sylvaticum as in Table 1. Population numbers correspond to Online Resource 1 and Fig. 1. Shown are population mean values stem along $1 \mathrm{~mm}$ just below a mid-stem leaf). Also the DA (Wilks' Lambda $=0.033 ; \chi^{2}=114.08 ; d f=41$; significance $0 ; p<0.0001$; Fig. 5b) based on the same set of characters showed a clear differentiation between the two species with the same characters as in the PCA contributing most strongly to the separation. The highest scores (between 0.20 and 0.32) were reached by petiole length of a lowermost leaf, number of glandular hairs on the stem along $1 \mathrm{~mm}$ just below a mid-stem leaf, width of petal lobe, petal length, length of the longest trichome on the margin of a mid-stem leaf along $1 \mathrm{~mm}$ just below the tip of the leaf and ratio petal length/ sepal length, followed by the ratio distance from the basis to the widest part of the petal/petal length, width of hyaline margin of sepal and number of eglandular hairs on the stem along $1 \mathrm{~mm}$ just below a mid-stem leaf.

The PCA of stolon leaf (SL) characters also showed a clear separation between C. subtriflorum and C. sylvaticum. 

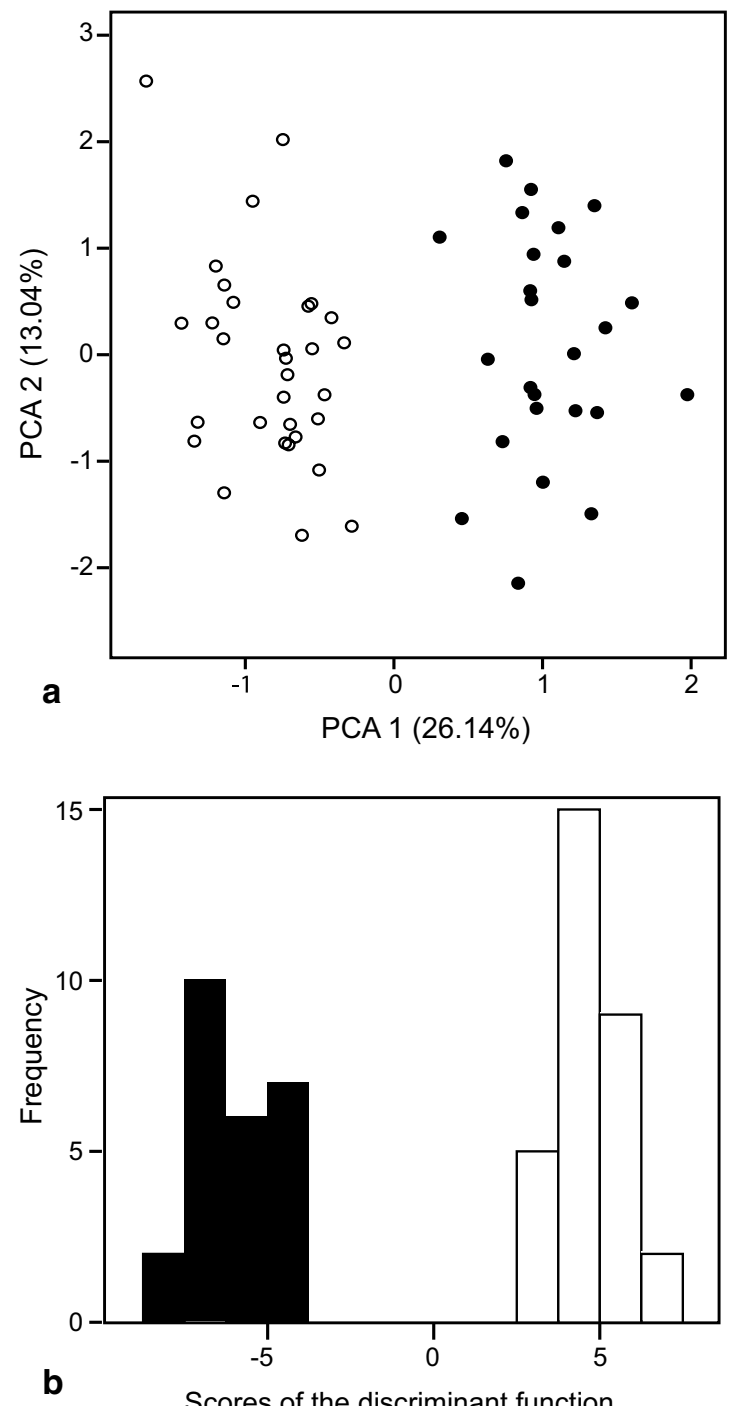

Fig. 5 Morphological differentiation between Cerastium subtriflorum (black) and C. sylvaticum (white), overlap of both in $\mathbf{d}$ is in grey. a Principal component analysis (PCA); b histogram of discriminant

The first three PCA axes explained 52.73, 22.79 and 12.25\% of the total variation (Fig. 5c). The characters contributing most to the separation along the first axis, i.e. those having highest component scores (between 0.77 and 0.88), were width of a stolon leaf, ratio length of a stolon leaf/width of a stolon leaf and petiole length of a stolon leaf. The same variables had the highest scores (between 0.56 and 0.78 ) in the DA (Wilks' Lambda $=0.318 ; \chi^{2}=34.949 ; d f=7$; significance $0.00 ; p<0.0001$ ), even though there was some overlap between the scores of the discriminant functions of $C$. subtriflorum and C. sylvaticum (Fig. 5d).

The PCA and the DA of capsule and seed characters (Wilks' Lambda $=0.405 ; \chi^{2}=29.838 ; d f=14$; significance $0.08 ; p>0.0001)$ did not show a separation between the two species (not shown).
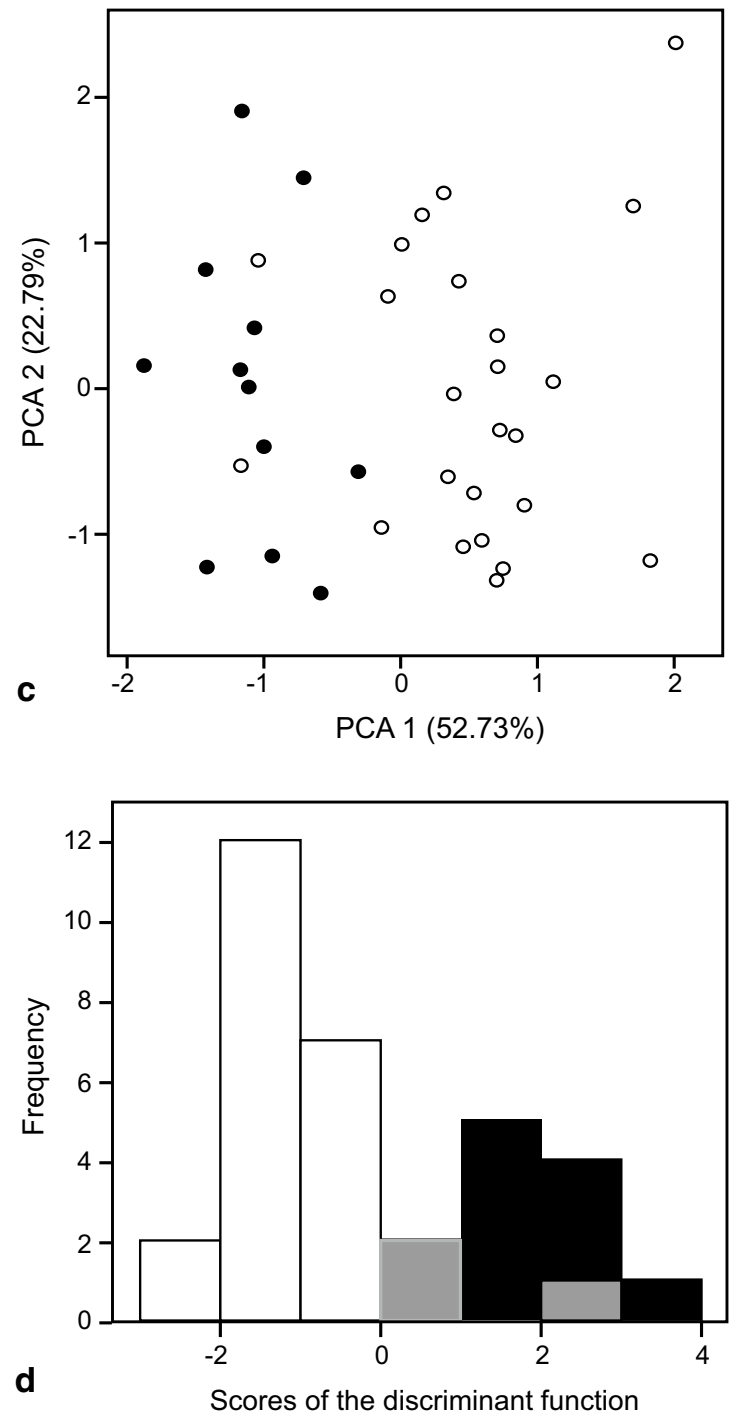

analysis (DA) of all characters except stolon leaf, capsule and seed characters. $\mathbf{c}$ PCA; $\mathbf{d}$ histogram of DA of stolon leaf characters

\section{Discussion}

South-eastern Alpine endemic Cerastium subtriflorum and more widespread C. sylvaticum are sister species, which are genetically (Figs. 2, 3) and morphologically (Fig. 5) clearly divergent and differ significantly also in their genome size (Fig. 4). The relationships to other Cerastium taxa remain unclear, but they clearly do not belong to the $C$. alpinum L. (=C. lanuginosum; tetraploid C. eriophorum from this group was included in the analyses) and C. latifolium alliances (Fig. 2) as suggested previously (Reichenbach 1841; Graebner and Correns 1918; Niketić 2007). In the ITS tree C. fontanum was positioned among the out-group taxa, whereas in the plastid tree it was included in the clade with $C$. subtriflorum and C. sylvaticum. However, in a 
phylogenetic tree based on a denser taxonomic and population sampling (Frajman, unpublished results) accessions of the $C$. fontanum alliance appeared more distant. Cerastium subtriflorum and $C$. sylvaticum thus do not belong to C. sect. Caespitosa as suggested by Božo Friedrich (1969), but rather form an independent evolutionary lineage within European tetraploid Cerastium.

Whereas C. sylvaticum is a typical forest understory species, C. subtriflorum inhabits exposed cliffs and rocks in the forests, but also rocky habitats above the timberline in the Julian Alps. Whereas the distribution of C. sylvaticum in the central part of its distribution area is more or less continuous, that of $C$. subtriflorum is split into three main disjunct areas, in the Julian Alps, in the Kamnik area and in the Sava valley (populations 1-2, 5-6 and 7-9, respectively, Fig. 1). The continuous distribution likely enables gene flow in $C$. sylvaticum, resulting in low genetic divergence in ITS sequences and presence of only one haplotype within the central part of the species' distribution. It is also likely that $C$. sylvaticum persisted Pleistocene glaciations in a single refugium in this area. Magri et al. (2006) suggested that beech (Fagus sylvatica) forests spread to Central and Northern Europe from their refugium in the northernmost Balkan Peninsula and it is plausible that also C. sylvaticum followed the same route, along with other understory species such as Cyclamen purpurascens (Slovak et al. 2012), Veronica chamaedrys (Bardy et al. 2010) and Knautia drymeia (Rešetnik et al. 2016). To get a better understanding of the evolutionary history of C. sylvaticum, additional populations from the entire distribution area would need to be sampled.

Despite the fact that the area of $C$. subtriflorum sampled for genetic analyses is comparable to that of C. sylvaticum (Fig. 1), there is much higher diversity of ribotypes and haplotypes in this species (Fig. 2). Whether this difference between $C$. sylvaticum and C. subtriflorum results from the presently continuous vs. fragmented distribution ranges or rather from survival in one vs. several glacial refugia remains unclear. As populations of C. subtriflorum are small and fragmented, stochasticity of genetic drift (faster fixation or elimination of mutations) is likely more pronounced (Freeland et al. 2011; Masel 2011). On the other hand, multiple Pleistocene refugia have been suggested for several species in the western Balkan Peninsula (e.g. Surina et al. 2011) and the present three disjunct distribution areas might have been a result of vicariance in the Pleistocene. Whereas the sequence data are inconclusive regarding the relationships among the three population groups, the AFLP NeighbourNet shows that population 6 is nested within populations 1-4 from the Julian Alps, whereas the Sava valley populations (7-9) are separated by several shared splits (Fig. 3b). High genetic divergence of population 8 from the Sava valley indicated by a long split from the other populations as well as $100 \%$ BS support in the AFLP NJ tree (Fig. 3a, b) is difficult to explain, as the species is rather continuously distributed in this area of the Sava river valley. Some specimens collected from this locality deposited at the herbarium $\mathrm{W}$ have intermediate characters between $C$. subtriflorum and $C$. sylvaticum, and it might be that ancient hybridisation caused the genetic peculiarity of this population, which was probably maintained due to limited gene flow with other surrounding populations.

Both studied species often grow in close vicinity (authors' personal observation) in the areas where their distribution ranges overlap (Fig. 1). Hybridisation between Cerastium species was suggested to be relatively common (Buschmann 1938; Khalaf and Stace 2000; Niketić 2007) and is evidenced also by our data. Whereas there is no strong indication of hybridisation in the ITS and AFLP data, in the plastid tree (Fig. 2) population 6 of C. subtriflorum from central Slovenia is positioned within the $C$. sylvaticum clade. Such a discordant pattern between the nuclear and the plastid phylogeny might result from chloroplast capture (Rieseberg and Soltis 1991; Tsitrone et al. 2003; Frajman et al. 2009) via hybridisation, that is, recent introgression of $C$. sylvaticum into population 6 of $C$. subtriflorum. Also in the AFLP NJ tree this population is the most divergent, which might also be caused by hybridisation with $C$. sylvaticum. There are also some morphological features, which might indicate a hybrid origin of this population. The petal length is close to the minimal length for C. subtriflorum (C. sylvaticum has shorter petals than C. subtriflorum), the lowermost leaves on a lateral shoot are slightly petiolate (which is characteristic for $C$. sylvaticum) and glandular hairs on a leaf margin are absent; the latter is characteristic for $C$. sylvaticum, but present also in some $C$. subtriflorum individuals from other populations.

\section{Taxonomic treatment}

In agreement with previous studies (Peverina 1982; Jalas 1993; Vreš 1996, 2007), the main morphological characters distinguishing the two species are petal size and the shape of lowermost stem and stolon leaves, which are petiolate in C. sylvaticum and sessile in C. subtriflorum. Moreover, $C$. subtriflorum individuals growing in lowlands have mainly glandular hairs on the stem, but those growing above the timberline usually lack them, having only eglandular ones, which renders them similar to C. sylvaticum. Some additional characters with discriminatory value between the two species are shown in Online Resource 6 and are included in the identification key and the species descriptions below. In cases when both length and width are listed, they always appear in this order. 


\section{Identification key}

Although trait values of some characters overlap, a combination of characters allows straightforward discrimination between the two taxa. The most discriminating characters are bold.

1a. 9.5) 17-41.5 (50) cm high perennial with 0-1 (2) glandular hairs on the stem along a 1-mm section below a mid-stem leaf. Mid-stem leaves (16.3) 25.3-47.2 (56.5) $\times(6.6) 7.5-16.3$ (17.9) $\mathrm{mm}$, with attenuate to cuneate basis. Lowermost leaves petiolate with (2.3) 5.1-13.8 (16.0)-mm-long petioles, (4.1) 4.8-10.4 (13.4) mm wide. Stolon leaves with (1.7) 5.3-10.8 (13.0)-mm-long petioles, (4.5) 5.9-15.3 (18.5) mm wide, (1.3) 1.5-2.5 (2.7) times longer than wide. Petals (5.1) 5.3-8.0 (8.3) mm long, 1.1-1.7 (2.2) times longer than sepals, petal lobes $(0.8)$ 0.9-1.5 (1.6) $\mathrm{mm}$ wide C. sylvaticum

1b. (5) 6.5-27.5 (30) $\mathrm{cm}$ high perennial with 0-16 (17) glandular hairs on the stem along a $1-\mathrm{mm}$ section below a mid-stem leaf. Mid-stem leaves (8.1) 11.6-31.5 (33.3) $\times(3.1) 4.1-12.1$ ( 15.0) $\mathrm{mm}$, with rounded to attenuate basis. Lowermost leaves sessile, (2.6) 3.0-7.0 (8.6) $\mathrm{mm}$ wide. Stolon leaves with 0-5.6 (5.7)-mm-long petioles, (2.9) 3.0-7.1 (7.2) mm wide, 2.1-3.3 (3.4) times longer than wide. Petals (7.3) 7.4-11.8 (12.4) mm long, (1.4) 1.5-2.6 times longer than sepals, petal lobes (1.0) 1.3-2.6 (2.8) $\mathrm{mm}$ wide C. subtriflorum

Cerastium subtriflorum (Rchb.) Pacher, Jahrb. Naturh. Landesmus. Kärnten 18: 104. 1886. $\equiv$ C. lanuginosum var. subtriflorum Rchb., Icon. Fl. Germ. Helv. 5: 38. 1842. $\equiv$ Cerastium latifolium var. subtriflorum (Rchb.) Rchb., Icon. Fl. Germ. Helv. 5: 38. 1842. ECerastium. alpinum var. subtriflorum (Rchb.) Fiori \& Paol., Fl. Anal. Ital. 1: 353. 1898.-TYPE: [Slovenia] "Krain, Mangart-Berg”, H. Freyer in Fl. Germ. Exsiccata, Centuria 15, collection number 1493 (lectotype designated here: PRC 456663 [photo!]; isolectotype: LJM!; no original material found at B, M, W, WU). = Cerastium sonticum Beck, Österr. Bot. Zeitschr. 58: 1. 1908.-TYPE: [Slovenia] "Küstenland, Modreja", 23 May 1907, G. Beck (lectotype designated here: PRC 456594 [photo!]; isolectotypes: LJU, PR, PRC, TSB, W, WU; several syntypes in PRC [photo!]).

= Cerastium sonticum subsp. savense Gartner, Feddes Repert. (Beih.) 113: 17. 1939._-LECTOTYPE (designated here): [Slovenia] "Krain. Mitor_Fall b. Trifail", May 1910, Arbesser (GZU 000273496 [web!]).-SYNTYPES: [Slovenia] "Steiermark. Graschnitzgraben, zw. Römerbad u. Geirach”, 3 Jun 1911, R. Czegka (GZU 000273494 [web!]);
[Slovenia] "Graschnitztal bei Römerbad", 3 Jun 1911, $R$. Czegka; [Slovenia] "In rupestribus udis ad cataractam 'Mitala' prope Sagor", Jul 1907, Hayek (WU 0066047!, WU 0066045 [web!], WU 0066046 [web!], GZU 000273495 [web!]).

= Cerastium sonticum subsp. udinense Gartner, Feddes Repert. (Beih.) 113: 18. 1939.

Description: Hirsute and glandular perennial, with ascending stems (5) 6.5-27.5 (30) cm high and 0.5-1.5 mm thick on their basis, having 4-6 (7) internodes below the main dichasium, internode adjacent to a mid-stem leaf (9) 11.8-78.8 (89) $\mathrm{mm}$ long. Stem along 1-mm-long section just below a mid-stem leaf with 0-16 (17) glandular and 0-9 (13) eglandular hairs, the longest being (0.3) 0.4-0.8 (1.0) mm long. Mid-stem leaves sessile, elliptical to ovate-lanceolate, (8.1) 11.6-31.5 (33.3) ×(3.1) 4.1-12.1 (15.0) mm, (1.9) 2.2-3.4 (3.9) times longer than wide, widest at $0.4-0.5(0.8)$ of the length, with rounded to attenuate basis with an angle of (56) $58-108(125)^{\circ}$ and broadly acute apex with an angle of (58) 62-91 (94) ${ }^{\circ}$. Upper leaf surface glabrous with 2-12 (15) eglandular hairs per $\mathrm{mm}^{2}$. Margin of mid-stem leaves along a 1-mm section just below the tip of the leaf with $0-4$ (8) glandular and (4) 5-13 (14) eglandular hairs, the longest being (0.5) 0.6-1.2 (1.3) mm long. Lowermost leaves sessile, elliptical to ovate-lanceolate, sometimes oblanceolate, (7.0) 8.4-18.1 (25.4) ×(2.6) 3.0-7.0 (8.6) mm, (2.0) 2.3-3.6 (4.4) times longer than wide, widest at 0.4-0.7 (0.8) of the length, with attenuate to cuneate, sometimes rounded basis with an angle of (28) 36-77 (93) ${ }^{\circ}$ and broadly acute apex with an angle of (71) 74-112 (114) ${ }^{\circ}$; upper leaf surface glabrous. Stolon leaves elliptical to ovate-lanceolate, (7.2) 7.4-20.6 (20.9) $\times(2.9)$ 3.0-7.1 (7.2) mm, 2.1-3.3 (3.4) times longer than wide, widest at $0.5-0.6$ of the length, with $0-5.6$ (5.7)-mm-long petioles. Leaf blade basis attenuate to cuneate with an angle of (42) 43-87 (91) and broadly acute apex with an angle of (71) $72-115(116)^{\circ}$; upper leaf surface glabrous. Inflorescence (18) 22.6-112.6 (134) mm long, with peduncles of terminal flowers (9) 12.1-37.2 (40) mm long, with (10) 11-19 (21) trichomes along 1-mm section. Sepals (3.7) 4.0-5.3 (5.5) × 1.3-2.0 mm, (0.4) 2.1-3.5 (3.8) times longer than wide, widest at $0.4-0.5(0.6)$ of the length, with $0.3-0.5 \mathrm{~mm}$ wide hyaline margin, hairy with $0.2-0.4-\mathrm{mm}-$ long trichomes. Petals (7.3) 7.4-11.8 (12.4) $\times(2.0)$ 2.5-4.6 (5.2) $\mathrm{mm}$, deeply emarginated, petal lobes (1.0) 1.3-2.6 (2.8) mm wide. Petals (1.4) 1.5-2.6 times longer than sepals, (2.0) 2.1-3.2 (3.6) times longer than wide, widest at $0.6-0.8$ of the length, from the basis to the incision (3.9) 4.8-7.7 (8.3) $\mathrm{mm}$ long, which corresponds to (0.4) $0.5-0.7$ of the total petal length. Capsules 6.3-9.7 $(10.5) \times(2.0) \quad 2.6-3.5$ (3.8) mm, (2.2) 2.3-3.2 (3.6) times longer than wide, widest at $0.3-0.5$ of the length, slightly curved to straight. Capsule teeth 1.0-1.6 (1.7) $\mathrm{mm}$ long and 
0.4-0.6 (0.7) mm wide, (2.2) 2.3-3.3 (3.5) times longer than wide. Seeds $(0.8) 0.9-1.3(1.4) \times 0.6-1.1 \quad$ (1.2) $\mathrm{mm}, 1.0-1.7$ (1.9) times longer than wide, with tubercles 0.06-0.11 (0.14) $\mathrm{mm}$ long and (0.07) $0.09-0.17 \mathrm{~mm}$ wide. $2 n=36$ (Söllner 1954; Rice et al. 2015).

Distribution area: Endemic to south-eastern Alps (Julian Alps in Slovenia and Italy), central Slovenia (Kamnik and Nevljica regions) and the Sava river valley (Zasavje and Posavje; Fig. 1).

Habitats: From lowlands to the (sub)alpine belt at around $2000 \mathrm{~m}$, on calcareous substrate. In forests on humid rocky places and cliffs and on rocky (sub)alpine grasslands and screes.

Cerastium sylvaticum Waldst. \& Kit., Descr. Ic. Pl. Rar. Hungar. 1: 100, t 97. 1802.-LECTOTYPE: "Hungarn", s.d., Waldstein (PR 502329/746 [photo!], plate 11, selected/ designed by Chrtek and Skočdopolova (1982)).-SYNTYPE: "Ungarn", P. Kitaibel (WU 0066043 [web!]).

= Cerastium microcarpum Kit., Kanitz, Linnaea 32:523. 1863.- TYPE: "Capsula subrotunda minima. A Wolny cum quaestione an Cerastium", Herbar Kitaibel Mus. Nat. Hung fasc. XIII, no. 389 [https://gallery.hungaricana.hu/en/Herba rium/3535] (lectotype designated here: BP s.n. [web!]). = Cerastium umbrosum Kit., Kanitz, Linnaea 32: 515-516. 1863. $\equiv$ Cerastium sylvaticum subsp. umbrosum (Kit.) Beck, Fl. Nieder-Österreich: 368. 1890. —TYPE: [Croatia] "In monte Merszin”, Herbar Kitaibel Mus. Nat. Hung fasc. XIII, no. 350 [https://gallery.hungaricana.hu/en/Herbarium/3561] (lectotype designated here: BP s.n [web!]).

Description: Hirsute and glandular perennial, with ascending stems (9.5) 17-41.5 (50) cm high and 0.5-2 mm thick on their basis, having (4) 5-7 (8) internodes below the main dichasium, internode adjacent to a mid-stem leaf (14) 26.8-100 (115) mm long. Stem along a 1-mm section just below a mid-stem leaves with 0-1 (2) glandular and 5-12 (13) eglandular hairs, the longest being (0.5) 0.6-0.8 (0.9) $\mathrm{mm}$ long. Mid-stem leaves sessile, elliptical to lanceolateelliptical, (16.3) 25.3-47.2 (56.5) ×(6.6) 7.5-16.3 (17.9) mm wide, (2.3) 2.4-3.9 (4.2) times longer than wide, widest at $0.5-0.6(0.7)$ of the length, with attenuate to cuneate basis with an angle of (33) $36-71(89)^{\circ}$ and broadly acute to broadly acuminate apex with an angle of (53) 55-91 (104) ${ }^{\circ}$. Upper leaf surface glabrous with 2-7(10) eglandular hairs per $\mathrm{mm}^{2}$. Margin of mid-stem leaves along a 1-mm section just below the tip of the leaf with 0-1 glandular and 3-8 eglandular hairs, the longest being (0.2) 0.4-0.7 (0.9) $\mathrm{mm}$ long. Lowermost leaves petiolate with (2.3) 5.1-13.8 (16.0)-mmlong petioles, oblanceolate to spatulate, (12.5) 12.9-25.8 (32.0) $\times(4.1) 4.8-10.4$ (13.4) mm, (1.7) 1.9-3.3 (3.4) times longer than wide, widest at 0.5-0.7 (0.8) of the length, with attenuate to cuneate basis with an angle of (34) 41-66 (72) ${ }^{\circ}$ and broadly acute to broadly acuminate apex with an angle of (62) $70-114(121)^{\circ}$. Stolon leaves oval to ovate, sometimes lanceolate to oblanceolate, (11.8) 12.0-24.7 (30.6) $\times(4.5)$ 5 .9-15.3(18.5) mm, (1.3) 1.5-2.5 (2.7) times longer than wide, widest at $0.4-0.6$ of the length with (1.7) $5.3-10.8$ (13.0)-mm-long petioles. Leaf blade basis attenuate to cuneate with an angle of (43) 47-95 (116) ${ }^{\circ}$ and broadly acute to mucronate apex with an angle of (75) 78-121 (124) ${ }^{\circ}$. Inflorescence (20) 27.6-138.8 (225) mm long, with peduncles of terminal flowers (9)13.1-33.4 (49.5) mm long, with (10) 11-19 (24) trichomes along a 1-mm-long section. Sepals (3.1) 3.6-5.8 (6.5) ×1.1-1.8 (1.9) mm, (2.6) 2.7-4.0 (4.6) times longer than wide, widest at $(0.3) 0.4-0.5(0.6)$ of the length, with 0.1-0.4 (0.6) $\mathrm{mm}$ wide hyaline margin, hairy with (0.1) 0.2-0.4-mm-long trichomes. Petals (5.1) 5.3-8.0 (8.3) $\times(1.5) 2.0-3.0$ (3.6) $\mathrm{mm}$, deeply emarginate, petal lobes (0.8) 0.9-1.5 (1.6) mm wide. Petals 1.1-1.7 (2.2) times longer than sepals, (2.2) 2.3-3.5 (3.9) times longer than wide, widest at (0.4) $0.5-0.7$ of the length, from the basis to the incision (3.1) 3.2-4.8 (5.2) $\mathrm{mm}$ long, which corresponds to $0.5-0.7$ of the total petal length. Capsules (5.7) 6.0-9.4 (10.2) ×(2.0) 2.3-3.5 (3.6) mm, (2.0) 2.2-3.3 (3.4) times longer than wide, widest at (0.3) $0.4-0.6$ of the length, curved to straight. Capsule teeth (0.7) 0.9-1.6 (1.9) mm long and (0.3) 0.4-0.6 mm wide, (1.8) 2.0-2.9 (3.2) times longer than wide. Seeds $0.8-1.2(1.4) \times(0.7) \quad 0.7-0.9(1.0) \mathrm{mm}$, (1.0) 1.1-1.4 (1.5) times longer than wide, with tubercles (0.05) 0.05-0.08 mm long and (0.06) 0.08-0.147 (0.16) mm wide. $2 n=36$ (Van Loon 1980; Rice et al. 2015).

Distribution area: Central and eastern Europe (Slovenia, Croatia, Bosnia and Hercegovina, Serbia, Montenegro, Austria, Czech Republic, Slovakia, Hungary) and disjunctly in Albania, Italy, Romania, SW Ukraine, Moldova, N Poland (Jalas and Suominen 1983; Fig. 1).

Habitats: From lowlands to $700 \mathrm{~m}$; shady and humid forests and scrublands, forest margins, along streams and rivers.

Acknowledgements Open access funding provided by University of Innsbruck and Medical University of Innsbruck. We thank all collectors listed in Online Resource 1, especially I. Dakskobler, M. Niketić and B. Vreš. The curators of the herbaria B, IB, LJM, LJU, M, PR, PRC, TSB, WU and ZA provided herbarium material for morphometric analyses and pictures of type specimens or looked for type material. M. Magauer, D. Pirkebner, D. Stešević and I. Rešetnik helped with laboratory work and M. Magauer with production of Fig. 1. We are grateful to M. J. Kocjan for photographs and herbarium material used in morphometric analyses. We thank two anonymous reviewers and the associate editor M. Ronikier for valuable comments and suggestions.

\section{Compliance with ethical standards}

Conflict of interest The authors declare they have no conflict of interest. 
Open Access This article is distributed under the terms of the Creative Commons Attribution 4.0 International License (http://creativeco mmons.org/licenses/by/4.0/), which permits unrestricted use, distribution, and reproduction in any medium, provided you give appropriate credit to the original author(s) and the source, provide a link to the Creative Commons license, and indicate if changes were made.

\section{Information on Electronic Supplementary Mate- rial}

Online Resource 1. Studied populations of Cerastium subtriflorum and C. sylvaticum and four out-group taxa. The distribution of populations used in phylogenetic, relative genome size and morphometric analyses and all inspected populations of $C$. subtriflorum (from herbaria IB, LJU, TSB, W, WU and ZA) is shown in Fig. 1.

Online Resource 2. ITS alignment. Identifiers following the species names are GenBank numbers.

Online Resource 3. Plastid alignment. Identifiers following the species names are GenBank numbers.

Online Resource 4. Character states of Cerastium subtriflorum and $C$. sylvaticum from morphometric analyses of all characters excluding capsule and seed characters.

Online Resource 5. Character states of Cerastium subtriflorum and $C$. sylvaticum from morphometric analyses of capsule and seed characters. Online Resource 6. Boxplot diagrams of morphological characters discriminating between Cerastium subtriflorum and C. sylvaticum.

\section{References}

Alvarez N, Thiel-Egenter C, Tribsch A, Holderegger R, Manel S, Schönswetter P, Taberlet P, Brodbeck S, Gaudeul M, Gielly L, Küpfer P, Mansion G, Negrini R, Paun O, Pellecchia M, Rioux D, Schüpfer F, van Loo M, Winkler M, Gugerli F (2009) History or ecology? Substrate type as a major driver of spatial genetic structure in Alpine plants. Ecol Letters 12:632-640. https://doi. org/10.1111/j.1461-0248.2009.01312.x

Arrigo N, Tuszynski JW, Ehrich D, Gerdes T, Alvarez N (2009) Evaluating the impact of scoring parameters on the structure of intra-specific genetic variation using RawGeno, an R package for automating AFLP scoring. BMC Bioinf 10:33. https://doi. org/10.1186/1471-2105-10-33

Bardy K, Albach DC, Schneeweiss GM, Fischer MA, Schönswetter P (2010) Disentangling phylogeography, polyploid evolution and taxonomy of a woodland herb (Veronica chamaedrys group, Plantaginaceae s.1.) in southeastern Europe. Molec Phylogen Evol 57:771-786. https://doi.org/10.1016/j.ympev.2010.06.025

Beck G (1908) Bemerkungen uber Cerastium subtriflorum Reich. und C. sonticum n. sp. aus dem Isonzotale. Oesterr Bot Z 58:1-9

Bonin A, Bellemain E, Bronken Eidesen P, Pompanon F, Brochmann C, Taberlet $\mathrm{P}$ (2004) How to track and assess genotyping errors in population genetics studies. Molec Ecol 13:3261-3273

Brysting AK, Mathiesen C, Marcussen T (2011) Challenges in polyploid phylogenetic reconstruction: a case story from the arcticalpine Cerastium alpinum complex. Taxon 60:333-347

Buschmann A (1938) Über einige ausdauernde Cerastium-Arten aus der Verwandtschaft des $C$. tomentosum Linné. Feddes Repert 43:118-143

Caković D, Stešević D, Schönswetter P, Frajman B (2017) Long neglected diversity in the Accursed Mountains of northern Albania: Cerastium hekuravense is genetically and morphologically divergent from $C$. dinaricum. Pl Syst Evol 304:57-69. https://doi.org/10.1007/s00606-017-1448-1
Chrtek J, Skočdopolova B (1982) Waldstein's collection in herbarium of the National Museum in Prague. Sborn Nár Mus Praze 38B:201-238

Clement M, Posada D, Crandall KA (2000) TCS: a computer program to estimate gene genealogies. Molec Ecol 9:1657-1660

Frajman B, Eggens F, Oxelman B (2009) Hybrid origins and homoploid reticulate evolution within Heliosperma (Sileneae, Caryophyllaceae)-a multigene phylogenetic approach with relative dating. Syst Biol 58:328-345. https://doi.org/10.1093/sysbi o/syp030

Freeland JR, Kirk H, Petersen SD (2011) Molecular ecology, 2nd edn. Wiley-Blackwell, Chichester

Božo Friedrich H (1969) Caryophyllaceae. In: Rechinger K-H (ed) Hegi, G. (founder), Illustrierte Flora von Mitteleuropa 3(2), Lieferung 6, 2nd edn. C. Hanser, München, pp 853-932

Graebner P, Correns C (1918) Cerastium L. In: Ascherson P, Graebner P (eds) Synopsis der mitteleuropäischen Flora 5(1). Gebrüder Borntraeger, Leipzig, pp 625-690

Huson DH, Bryant D (2006) Application of phylogenetic networks in evolutionary studies. Molec Biol Evol 23:254-267. https:// doi.org/10.1093/molbev/msj030

IBM SPSS Statistics for Windows, version 24. IBM Corp., Armonk

Jalas J (1964) Cerastium L. (perennials). In: Tutin TG (ed) Flora Europea, vol. 1. Cambridge University Press, Cambridge, pp 136-145

Jalas A (1993) Cerastium L. ['perennial species']. In: Tutin TG, Burges NA, Chater OA, Edmondson JR, Heywood VH, Moore DM, Valentine DH, Walters SM, Webb DA (eds) Flora Europaea 1. Cambridge University Press, Cambridge, pp 164-171

Jalas J, Suominen J (1983) Atlas Florae Europaeae, Distribution of vascular plants in Europe 6. Helsinki, pp 102-103

Jogan N, Bačič T, Frajman B, Leskovar I, Naglič D, Podobnik A, Rozman B, Struglc-Krajšek S, Trčak B (2001) Gradivo za Atlas flore Slovenije. Center za kartografijo favne in flore, Miklavž na Dravskem polju

Kearse M, Moir R, Wilson A, Stones-Havas S, Cheung M, Sturrock Sm Buxton S, Cooper A, Markowitz S, Duran C, Thierer T, Ashton B, Mentiies P, Drummond A (2012) Geneious Basic: an integrated and extendable desktop software platform for the organization and analysis of sequence data. Bioinformatics 28:1647-1649

Khalaf MK, Stace A (2000) Breeding systems and relationships of the Cerastium tomentosum Group. Preslia 72:323-344

Krogulevich RE (1971) Rol poliploidii v genezise vysokogornoi flory Stanogovo Nagorya. [The role of polyploidy in the genesis of the alpine flora of the Stanovoye Nagorye mountains.] In: Klimashevsky EL (ed) Ekologiya flory Zabaykalva. [The ecology of flora of the Trans-Baikal region], Akademii Nauk SSSR, Irkutsk, pp 115-214 [in Russian]

Kutnjak D, Schönswetter P, Dullinger S, Kuttner M, Niketić M, Frajman B (2014) Escaping to the summits: phylogeography and predicted range dynamics of Cerastium dinaricum, an endangered high mountain plant endemic to the western Balkan Peninsula. Molec Phylogen Evol 78:365-374. https://doi.org/10.1016/j. ympev.2014.05.015

Lewis PO (2001) A likelihood approach to estimating phylogeny from discrete morphological character data. Syst Biol 50:913-925

Magri D, Vendramin GG, Comps B, Dupanloup I, Geburek T, Gömöry D, Latalowa M, Litt T, Paule L, Roure JM, Tantau J, van der Knaap WO, Petit RJ, de Beaulieu JL (2006) A new scenario for the Quaternary history of European beech populations: palaeobotanical evidence and genetic consequences. New Phytol 171:199-221. https:// doi.org/10.1111/j.1469-8137.2006.01740.x

Masel J (2011) Genetic drift. Curr Biol 21:R837-R838

Mayer E (1960a) Endemicne cvetnice obmocja jugovzhodnih apneniških Alp, njihovega predgorja in ilirskega prehodnega ozemlja. In: Lazar 
J (ed) Zbornik ob 150-letnici botanicnega vrta v Ljubljani. Univerza v Ljubljani, Ljubljana, pp 26-45

Mayer E (1960b) Südöstliches Alpenvorland-ein pflanzengeographisches Prachtgebeit. Jubiläumsjahrbuch Jahrbuch des Vereins zum Schutze der Alpenpflanzen und -Tiere 25:136-144

Müller K (2005) SeqState-primer design and sequence statistics for phylogenetic DNA data sets. Appl Bioinform 4:65-69

Nei M, Li WH (1979) Mathematical model for studying genetic variation in terms of restriction endonucleases. Proc Natl Acad Sci USA 76:5269-5273

Niketić M (2007) Endemic representatives of genus Cerastium L. in southeastern Europe. Taxonomy, chorology and ecology. PhD Thesis, University of Belgrade, Belgrad (in Serbian, with English abstract)

Niketić M, Siljak-Yakovlev S, Frajman B, Lazarević M, Stevanović B, Tomović G, Stevanović V (2013) Towards resolving the systematics of Cerastium subsect. Cerastium (Caryophyllaceae): a cytogenetic approach. Bot J Linn Soc 172:205-224. https://doi.org/10.1111/ boj. 12050

Nylander JAA (2004) MrAIC pl. Program distributed by the author. Evolutionary Biology Centre. Uppsala University, Uppsala

Pacher D (1886) Systematische Aufzählung der in Kärnten wildwachsenden Gefässpflanzen. Jahrb Naturhist Landesmuseums Kärnten 18:81-284

Pawłowski B (1970) Remarques sur l'endémisme dans la flore des Alpes et des Carpates. Vegetatio 21:181-243

Petit RJ, Brewer S, Bordács S, Burg K, Cheddadi R, Coart E, Cottrell J, Csaikl UM, van Dam B, Deans J, Espinel S, Fineschi S, Finkeldey R, Glaz I, Goicoechea PG, Svejgaard Jensen J, König AO, Lowe AJ, Kremer A (2002) Identification of refugia and post-glacial colonisation routes of European white oaks based on chloroplast DNA and fossil pollen evidence. Forest Ecol Managem 156:49-74. https://doi. org/10.1016/S0378-1127(01)00634-X

Pignatti S (1982) Flora d'Italia 1. Edagricole, Bologna

Poldini L (2002) Nuovo Atlante corologico delle piante vascolari nel Friuli Venezia Giulia. Regione autonoma Friuli Venezia Giulia, Azienda parchi e foreste regionali. Universitá degli studi di Trieste, Dipartimento di biologia, Udine

R Core Team (2016) R: a language and environment for statistical computing. R Foundation for Statistical Computing, Vienna, Austria. Available at: https://www.R-project.org/

R Development Core Team (2012) R: a language and environment for statistical computing. R Foundation for Statistical Computing, Vienna, Austria. Available at: https://www.R-project.org

Rebernig CA, Schneeweiss GM, Bardy KE, Schonswetter P, Villasenor JL, Obermayer R, Stuessy TF, Weiss-Schneeweiss H (2010) Multiple Pleistocene refugia and Holocene range expansion of an abundant southwestern American desert plant species (Melampodium leucanthum, Asteraceae). Molec Ecol 19:3421-3443

Reichenbach L (1841) Icones Florae Germanicae et Helveticae, vol. 5

Rešetnik I, Frajman B, Schönswetter P (2016) Heteroploid Knautia drymeia includes $K$. gussonei and cannot be separated into diagnosable subspecies. Amer J Bot 103:1-14. https://doi.org/10.3732/ ajb. 1500506

Rice A, Glick L, Abadi S, Einhorn M, Kopelman NM, Salman-Minkov A, Mayzel J, Chay O, Mayrose I (2015) The Chromosome Counts Database (CCDB) - a community resource of plant chromosome numbers. New Phytol 206:19-26. https://doi.org/10.1111/nph.13191

Rieseberg LH, Soltis DE (1991) Phylogenetic consequences of cytoplasmic gene flow in plants. Evol Trends Pl 5:65-84

Ronquist F, Teslenko M, van der Mark P, Ayres DL, Darling A, Höhna S, Larget B, Liu L, Suchard MA, Huelsenbeck JP (2012) MrBayes 3.2: efficient Bayesian phylogenetic inference and model choice across a large model space. Syst Biol 61:539-542. https://doi.org/10.1093/ sysbio/sys029
Schmitt T (2009) Biogeographical and evolutionary importance of the European high mountain systems. Frontiers Zool 6:9. https://doi. org/10.1186/1742-9994-6-9

Schneider CA, Rasband WS, Eliceiri KW (2012) NIH Image to ImageJ: 25 years of image analysis. Nature Meth 9:671-675

Schönswetter P, Stehlik I, Holderegger R, Tribsch A (2005) Molecular evidence for glacial refugia of mountain plants in the European Alps. Molec Ecol 14:3547-3555. https://doi.org/10.1111/j.1365294X.2005.02683.X

Schönswetter P, Solstad H, Escobar García P, Elven R (2009) A combined molecular and morphological approach to the taxonomically intricate European mountain plant Papaver alpinum s.l. (Papaveraceae). Taxa or informal phylogeographical groups? Taxon 58:1326-1343

Slovák M, Kučera J, Turis P, Zozomová-Lihová J (2012) Multiple glacial refugia and postglacial colonization routes inferred for a woodland geophyte, Cyclamen purpurascens: patterns concordant with the Pleistocene history of broadleaved and coniferous tree species. Biol J Linn Soc 105:741-760

Söllner R (1954) Recherches cytotaxinomiques sur le genre Cerastium. Ber Schweiz Bot Ges 64:221-354

Surina B, Schönswetter P, Schneeweiss GM (2011) Quaternary range dynamics of ecologically divergent species (Edraianthus serpyllifolius and E. tenuifolius, Campanulaceae) within the Balkan refugium. J Biogeogr 38:1381-1393

Swofford DL (2002) PAUP*. Phylogenetic Analysis Using Parsimony (*and Other Methods), ver. 4.0 beta 10. Sinauer Associates, Sunderland

Tel-Zur N, Abbo S, Myslabodski D, Mizrahi Y (1999) Modified CTAB procedure for DNA isolation from epiphytic cacti of genera Hylocereus and Selenicereus (Cactaceae). Pl Molec Biol Rep 17:249-254

Tribsch A, Schönswetter P (2003) Patterns of endemism and comparative phylogeography confirm palaeoenvironmental evidence for Pleistocene refugia in the eastern Alps. Taxon 52:477-497. https://doi. org/10.2307/3647447

Tsitrone A, Kirkpatrick M, Levin DA (2003) A model for chloroplast capture. Evolution (Lancaster) 57:1776-1782

van de Peer Y, Wachter R (1997) Construction of evolutionary distance trees with TREECON for Windows: accounting for variation in nucleotide substitution rate among sites. Bioinformatics 13:227230. https://doi.org/10.1093/bioinformatics/13.3.227

Van Loon JC (1980) Chromosome number reports LXIX. Taxon 29:718-720

Vos P, Hogers R, Bleeker M, Reijans M, van de Lee T, Hornes M, Frijters A, Pot J, Peleman J, Kuiper M, Zabeau M (1995) AFLP: a new technique for DNA fingerprinting. Nucl Acids Res 23:4407-4414

Vreš B (1996) Agregata Cerastium subtriflorum in C. sylvaticum na jugovzhodnem obrobju Alp. PhD Thesis, Sveučilište u Zagrebu, Prirodoslovno-matematicki fakultet, Ljubljana-Zagreb, pp 1-149

Vreš B (2007) Caryophyllaceae (incl. Alsinaceae, Illecebraceae)— klinčnice. In: Martinčič A, Wraber T, Jogan N, Podobnik A, Turk B, Vreš B, Ravnik V, Frajman B, Strgulc-Krajšek S, Trčak B, Bačič T, Fischer MA, Eler K, Surina B (eds) Mala flora Slovenije. Ključ za določanje praprotnic in semenk. Četrta dopolnjena in spremenjena izdaja. Tehniška založba Slovenije, Ljubljana, p 967

Willner W, Di Pietro R, Bergmeier E (2009) Phytogeographical evidence for post-glacial dispersal limitation of European beech forest species. Ecography 32:1011-1018. https://doi.org/10.111 1/j.1600-0587.2009.05957.x

Wraber T (1990) Čaven, ein botanisch berühmter Berg in Slowenien. Carinthia II 180:195-210 